\title{
Education-to-Work Transitions during the COVID-19 Lockdowns in Britain, 2020-2021
}

\author{
Ken Roberts \\ Department of Sociology, University of Liverpool, Liverpool, England \\ Email: k.roberts@liverpool.ac.uk
}

How to cite this paper: Roberts, K. (2021). Education-to-Work Transitions during the COVID-19 Lockdowns in Britain, 2020-2021. Advances in Applied Sociology, 11, 564-584. https://doi.org/10.4236/aasoci.2021.1111049

Received: October 21, 2021

Accepted: November 27, 2021

Published: November 30, 2021

Copyright $\odot 2021$ by author(s) and Scientific Research Publishing Inc. This work is licensed under the Creative Commons Attribution International License (CC BY 4.0).

http://creativecommons.org/licenses/by/4.0/

\begin{abstract}
This paper uses official data, and the research conducted by policy think tanks and independent research organizations, to chart the experiences of Britain's COVID cohort who either spent the final year of their full-time education and/or their first year in the labour market wholly or partly under the pandemic lockdowns which began in March 2020 and continued, with interruptions, until July 2021. The data show that government's "no detriment" policies protected students from facing crucial examinations, and employees already in jobs were protected through furloughing. New entrants to the labour market were relatively unprotected. Yet despite the economic turbulence induced by the pandemic, lockdowns, followed by a "hard" Brexit at the end of 2020, rises in youth unemployment were confined to students seeking part-time jobs, and among them to particularly vulnerable groups, namely the least qualified and non-white ethnic minorities. However, it is argued that this success was at the cost of exacerbating ongoing trends with generally unwelcome consequences, specifically an increase in the number of higher education graduates entering jobs for which they are over-qualified, and an enlarged tail-end of low achievers who are at risk of becoming trapped in low-paid precarious work.
\end{abstract}

\section{Keywords}

Brexit, COVID-19, Education, Employment, Unemployment, Youth Transitions

\section{Introduction}

This paper assembles the available evidence on how the COVID-19 pandemic, lockdowns, then Brexit, affected young people in Britain who were completing their education and entering the labour market during 2020 and 2021. With ex- 
ceptions that will be identified, the evidence suggests that examination grades, rates of progression into and through upper secondary education, enrolments in higher education, and chances of obtaining subsequent employment, were unscathed. In these respects, the UK has not differed from most European countries. Up to mid-2021, a "hard" Brexit has had no discernible effects on transitions from education to work. The ensuing discussion leads to the conclusions that we must wait several years for the effects of the atypical events of 2020 and 2021 to become fully apparent, that longer-term changes are likely to have accelerated, but we will need more satisfactory metrics in order to identify exactly how the changes have impacted specific socio-demographic groups.

\section{The Pandemic and the Life Course}

A life course is an individual's journey from birth to death. These journeys are biologically inevitable facts of life. Then, based on this biology, every society constructs life stages associated with specific rights, responsibilities, risks and opportunities. These social constructions have filtered the impact of COVID-19 which began to spread in Britain and the rest of Europe early in 2020.

It was not until $9^{\text {th }}$ November 2020 that Pfizer announced a successful outcome of trials with its COVID-19 vaccine. The medical pandemic looked likely to end during 2021, but in Britain the social and economic impacts and after-effects had barely started. In 2021, The British Academy (2021) issued a report entitled Shaping the COVID Decade. The Academy's collective wisdom envisaged medium- and long-term implications for levels of trust, geographical and other inequalities, health outcomes, labour markets, and education and skills continuing throughout the 2020s. At the end of 2020 Britain was also on the verge of completing a "hard" Brexit, another event whose main consequences, like those of the medical pandemic, lay in the future.

The short-term 2020-2021 and the longer-term impacts of the COVID-19 pandemic and Brexit on people's lives in Britain and elsewhere have varied and will continue to vary by life stage. If infected, the frail elderly have been at greatest risk of COVID-related death. Even if the majority of citizens in post-working life were not infected in 2020 and 2021, they will have experienced shielding, voluntarily or otherwise. Britain's well-off older people (WOOPIES) lost regular visits to pubs and restaurants during lockdowns, plus days-out and vacations away from home. All who formerly enjoyed them lost coffee mornings and meetings of various associations, plus contact with children and grandchildren. The elderly always have the fewest years of life ahead in which to experience after-effects, but also the highest proportions of their remaining lives that are at risk.

Those hardest hit long-term are likely to include adults in mid- or later-working life who lost their occupations during the 2020 and 2021 lockdowns (Brewer et al., 2020; Cominetti, 2021). They will be part of the collateral damage of any Brexit and lockdown induced recession and economic restructuring. Premature termination of careers undermines hopes and plans for later life. Diminished ability to save means lower pensions during an extended later-life. State retirement pensions 
in Britain will not become available for people in their fifties in 2020 until they reach the age of 68 . Delayed starts to working life and building pension funds have the same (more distant) consequences.

The economically active who remained in employment may have experienced furloughing during 2020 and 2021. Some switched, by choice or instruction, wholly or partly, to working from home. In the spring of 2021, 29 percent of the workforce was working wholly from home (Ball, 2021). This has been technologically possible in many occupations throughout the age of the internet but the volume of travel to work and to meetings was barely affected pre-pandemic. Time alone will tell whether the post-pandemic normal will be a return to the old normal.

During 2020, young children's lives were locked down, or more accurately locked in their homes by closures of schools and nurseries, and reductions of contact with friends and relatives from outside their own family households. They were the age group who were locked-in for the greatest proportions of their already spent lifetimes, with unknown implications that could stretch throughout the rest of their lives.

However, it was youth and young adults who experienced the most widespread, unavoidable disruption to their lives during 2020, with potential longer-term implications, and with the most lifetime ahead in which to live with the pandemic's and Brexit's consequences. During the initial full lockdown (March 23 to May 28,2020 ), again in November 2020, and yet again from the beginning of 2021, public spaces where young people would normally gather were effectively shut: school playgrounds, university campuses and town centres. Young people lost their places of entertainment and for socialising freely. They lost access to normal places for social mingling in schools, colleges and universities, in sports facilities, cultural, political and religious associations. Normally vibrant night time economies fell silent. Distancing as part of a new normal meant goodbye (for how long?) to many business sectors in which young adults were well-represented among staff and customers, members or participants: spectator and participant sport, hospitality, entertainment and tourism. Around six million jobs were at risk in these sectors. Beyond this, there were enormous implications for the entire youth life stage. Sally Rooney's "normal people" were at risk of becoming historical fiction if distancing was to be part of a new normal (Rooney, 2019). Familiar processes of new household and family formation had to be suspended. Until the death of George Floyd during arrest by the Minneapolis police on May 25 2020, which inspired a global Black Lives Matter movement, young people's voices rarely broke into mainstream media. They could be interacting online in numerous ghettos, but voices only make an impact when bodies can converge in public spaces, when voices are amplified in mainstream media, and eventually find expression in ballot boxes.

The immediate and longer-term effects of the medical pandemic, lockdowns and Brexit will not be confined to, but here we focus on young people's education and employment, and their transitions from the former to the latter during 
2020 and early-2021.

\section{Methods}

This paper uses data produced routinely by government departments, especially but not only the Department for Education and the Department for Work and Pensions. These departments routinely publish data on participation by different age groups in different kinds of education, achieving various qualifications, in employment, unemployed and economically inactive. In addition, the UK's Office for National Statistics launched ad hoc surveys (necessarily online) during 2020 and 2021 which offer further information on young people's situations and responses amid the pandemic and lockdowns. Further relevant data has been produced by the Department for Health, and the Department for Culture, Media, Sport and Digital. The evidence in the following passages is also from research conducted by various policy "think tanks", research organisations and pressure groups representing educators, businesses and labour.

All this new data is set in the context of findings from previous decades of research into how the youth life stage had, and had not, been changing in the period prior to the outbreak of the COVID-19 pandemic.

\section{Education, Employment and the Youth Life Stage Experience in Britain during 2020 and 2021}

\subsection{Protection for "Insiders"}

All stages in young people's education were disrupted in 2020. Many pupils did not attend school from March until September. In October 2020 only 60 percent had been attending normally since the start of the new term (Major et al., 2020). This disruption continued into 2021. Most schools closed for most pupils during a second lockdown that began in November 2020. This lockdown was partly lifted in early December, to different extents in different parts of Britain, but a third full lockdown was imposed at the beginning of 2021 and most schools remained closed for most pupils at least until March. The extent to which learning was impaired was filtered by social class (Major \& Machin, 2020; Villadsen et al., 2020). Those taking public examinations in 2020 and 2021 were in limbo until the last possible moments, wondering how they would be graded. In 2020 they were uncertain as to whether normal examinations would be held and, in any case, the basis on which they would be assessed. University education went online in March 2020 and remained mainly or wholly online for most students throughout autumn, the following winter and spring 2021. No financial compensation was offered to students despite the impossibility of universities delivering a normal student experience. Unsurprisingly, 57 percent of 16 - 25 year olds who were students in 2021 felt that the pandemic had worsened their prospects (Schoon \& Henseke, 2021).

Young people in education in 2020 could be assured that their GCSE, BTEC and A-level grades would not be inferior to those awarded in previous years. In 
contrast, those who were about to enter the labour market were offered no equivalent assurances. In 2020, normal public examinations were cancelled or replaced by grades awarded on the basis of school-administered tests, teachers' assessments and predictions. An outcome was over-compensation and an acceleration of grade inflation. During the early-1990s, the proportions of GCSE grades awarded in England at A-C (now 9-4) rose slowly from 35 percent in 1990 to 41 percent in 1993 and this trend continued until 67 percent of awards were at these levels in 2019. In 2020 and 2021, there were boosts to 76 and 77 percent. In 2012, 27 percent of A-level entries were given $\mathrm{A}^{*}$ or $\mathrm{A}$. This had risen to 33 percent by 2019, and then jumped to 38 percent in 2020 and 45 percent in 2021. Universities were required to admit all potential students who had met the requirements in conditional offers of places. An outcome in 2020 was a record proportion of England's 18 - 19 year olds (around 40 percent) entering higher education directly from school or college. This seemed set to rise again in 2021 when 44 percent applied for university entry. Students who were approaching the end of their undergraduate courses in 2020 were assured that they would suffer "no detriment", and the proportion of graduates with first class honours rose from 28 percent in 2019 to 35 percent in 2020. In 2021, there were demands that the latest cohorts whose schooling was disrupted from spring 2020 onwards should not be disadvantaged vis-à-vis their immediate predecessors. Thus the proportion of 16 year olds who can enrol for courses that will qualify them for higher education, then the proportion of the age group entering universities, could rise further. An increase in enrolments on postgraduate courses looked likely. In 2021, 32 percent of 16 - 25 year olds expected to exit education with a postgraduate qualification. At that time just 15.5 percent of 29 - 31 year olds were this well qualified (Schoon \& Henseke, 2021). However, this will depend on the government's willingness to fund a further expansion of higher education, and the alternative opportunities that await 16 then 18 year olds.

In 2020, the UK government protected existing businesses and employees, the former with grants, loans and council tax holidays, the latter with a furlough scheme and an equivalent scheme for the self-employed. In July 2020, over 11 million employees were on one of these job retention schemes. This means that almost a third of the workforce was effectively out-of-work except that almost two-thirds of employees on furlough continued to perform some of their normal work, usually in exchange for wage top-ups from their employers (Adams-Prassl et al., 2020). During April 2020, the first full month of the first national lockdown, hours actually worked by employees fell by 20 percent but paid hours by only 1.5 percent. This was a furlough effect (Office for National Statistics, 2021a). The main government measures accompanying lockdowns in 2020 and 2021 protected existing employees, the insiders, mainly through furloughing.

This was unlike government initiatives in the 1980s when "lame ducks", which could be major shipyards, car assembly plants, coal mines or steel works, were allowed to sink and young people were advised to target employment in expanding sectors, which at that time were financial and other business services 
and ICT, which were located mainly in South-East England. The new jobs drew recruits from the increasing proportions of young people who were leaving education with impressive academic qualifications, particularly higher education graduates. The main government measure aimed at the less qualified, successive versions of youth training, did too little "lifting up" and too much churning (Roberts, 2020a).

Despite the government's job protection measures, in 2020, young employees were the most likely to be made redundant and to have their hours of work and pay reduced. In April 2020, the overall decline in hours of paid work was just 1.5 percent, but it was 5.4 percent among $16-17$ year olds, and 3.7 percent among those aged $18-21$. The proportion of the workforce on reduced furlough pay was 11 percent overall, but 29 percent among $16-17$ year olds, 22 percent among those aged $18-21$, and 13 percent of those aged $22-29$ (Office for National Statistics, 2021a). Young workers' vulnerability in 2020 was on account of their over-representation in retail, hospitality and leisure, the sectors that were hit hardest during lockdowns (Brewer \& Handscomb, 2020; Brewer et al., 2020; Wielgoszewska et al., 2020). Between March 2020 and March 2021, there was an 813,000 decline in the number of payrolled employees, and 54 percent of the decline affected under-25 year olds (Office for National Statistics, 2021b). Hence the spate of proposals during 2020 to address an impending crisis in youth labour markets (for example, Henehan, 2020; Trade Union Congress, 2020).

However, young employees in vulnerable sectors are often students who work part-time, temporarily or casually. Some who were furloughed must have celebrated being paid while they concentrated on their studies. Other young people's jobs in hospitality and retail are steps in their working lives when they pause before seeking, or while waiting to start, career jobs. Their most likely problem in 2020 was moving on. The government's priority was to protect the jobs of existing employees, mainly by furloughing whose availability was extended several times and eventually up to September 2021. In 2020, businesses that were making existing staff redundant or placing them on furlough were unlikely to recruit newcomers. The rise in unemployment during 2020 was due mainly to a slowdown in recruitment rather than a rise in job terminations (Brewer et al., 2020). The impact became visible during summer and autumn 2020 when levels of unemployment among 16 - 24 year olds rose from 11 percent in November 2019 to 15 percent in November 2020 (see Table 1).

\subsection{Outsiders}

The UK was a middling European country in its rates of youth unemployment preceding, during and at the end of 2020 when the medical pandemic was at the beginning of its end. The European countries with the smallest if any rises in youth unemployment during 2020 tended to be those with the lowest youth unemployment rates pre-pandemic (see Table 1). The countries that experienced the sharpest rises in 2020 tended to be those with the continent's highest youth unemployment rates at the start of the year. Like the UK, they have large 
Table 1. Unemployment rates.

\begin{tabular}{|c|c|c|c|}
\hline & $\begin{array}{c}\text { 16-64 November } \\
2020\end{array}$ & $\begin{array}{c}\text { 16-24 November } \\
2019\end{array}$ & $\begin{array}{c}\text { 16-24 November } \\
2020\end{array}$ \\
\hline Germany & 5 & 6 & 6 \\
\hline Czechia & 3 & 6 & 8 \\
\hline Netherlands & 4 & 7 & 9 \\
\hline Switzerland & 5 & 8 & 9 \\
\hline Austria & 5 & 9 & 10 \\
\hline Iceland & 6 & 9 & 10 \\
\hline Malta & 5 & 10 & 11 \\
\hline Hungary & 5 & 12 & 12 \\
\hline Norway & 5 & 10 & 12 \\
\hline Denmark & 6 & 10 & 13 \\
\hline Poland & 3 & 8 & 13 \\
\hline Bulgaria & 5 & 15 & 14 \\
\hline Latvia & 8 & 11 & 15 \\
\hline UK & 5 & 11 & 15 \\
\hline Slovenia & 5 & 8 & 16 \\
\hline Belgium & 6 & 15 & 18 \\
\hline Romania & 5 & 18 & 19 \\
\hline Slovakia & 7 & 17 & 20 \\
\hline Ireland & 8 & 11 & 20 \\
\hline Cyprus & 8 & 15 & 21 \\
\hline Finland & 8 & 18 & 21 \\
\hline France & 9 & 20 & 22 \\
\hline Luxembourg & 7 & 18 & 22 \\
\hline Estonia & 8 & 9 & 23 \\
\hline Portugal & 7 & 19 & 23 \\
\hline Sweden & 9 & 20 & 24 \\
\hline Croatia & 8 & 16 & 25 \\
\hline Lithuania & 10 & 15 & 28 \\
\hline Italy & 9 & 28 & 30 \\
\hline Greece & 16 & 35 & 33 \\
\hline Spain & 16 & 31 & 41 \\
\hline EU & 5 & 15 & 18 \\
\hline
\end{tabular}

Source: Eurostat News Release 4/2021, January 2021. 
service sectors including hospitality and tourism which experienced the heaviest lockdowns in 2020. Also, most European countries with high youth unemployment rates pre-pandemic have normalised "waiting" for a job that an applicant considers commensurate with his or her qualifications. Young people in these (mainly southern European) countries are willing to wait, families will provide whatever support is within their means, and employers will not penalise applicants who have spent months, even years, just waiting. In the UK, as in other northern European countries, waiting is less tolerated by all parties even though stepping down the occupational structure risks incurring long-term career penalties (see Vobemer \& Schuck, 2016).

Needless to say, there are exceptions to all the above generalisations. In Italy, a high youth unemployment country pre-pandemic, the rate changed little throughout 2020. Poland and Slovakia were low youth unemployment countries prepandemic but experienced above-average rises during 2020. These cases require country specific explanations, but the case featured in this paper is the UK. This country is unable to become one of Europe's low youth unemployment states. The UK has too many precarious jobs in distribution and service sectors. Europe's lowest youth unemployment rates cluster in countries with larger manufacturing sectors, and transition regimes in which specific courses in education and vocational training are linked relatively securely to specific types of employment.

Table 2 takes a more detailed look at trends in unemployment rates in the UK during 2020 and 2021. It divides youth into $16-17$ and $18-24$ year olds, and compares unemployment in successive quarters from the beginning of 2020 . Since 2015, 16 and 17 year olds have been required to continue in full-time learning, which usually means attending school or college, but they are able, as are older students, to seek and take part-time jobs. The table shows that the first lockdown, which initially ripped 20 percent from GDP, led to spikes in unemployment in all age groups. Youth, but not adult, unemployment rates recovered partly during a V-shaped rebound from recession (October-December 2020) in which 12 percent of GDP was regained. During early 2021 unemployment rates fell among adults and 18 - 24 year olds, but not among those aged $16-17$. Here the UK's experience resembled that of the larger EU countries where unemployment among 16 - 24 year olds remained stable or fell slightly in early 2021.

Table 2. UK Unemployment rates (in percentages).

\begin{tabular}{cccc}
\hline & $16-64$ & $16-17$ & $18-24$ \\
\hline January-March 2020 & 4.0 & 23.1 & 10.3 \\
April-June & 4.1 & 24.2 & 11.8 \\
July-September & 5.2 & 30.4 & 14.9 \\
October-December & 5.3 & 24.8 & 13.6 \\
January-March 2021 & 4.9 & 28.0 & 11.6 \\
April-June 2021 & 4.6 & 32.8 & 10.6 \\
\hline
\end{tabular}

Source: Office for National Statistics, Labour Force Surveys. 
Table 3 presents a further disaggregated view of what happened to levels of youth employment and unemployment in the UK during 2020-2021. Young people in each of the two age groups are split according to whether or not they reported that they were in full-time education. This has been legally obligatory for 16 and 17 year olds since 2015, but ever since then Labour Force Surveys have recorded a minority (just seven percent in spring 2021) who were not complying. They are a heterogeneous group, outside formal education for various lengths of time and reasons. This minority needs to be further disaggregated in order to make sense of their chances of being employed and unemployed. For present purposes we can focus on the 93 percent who were in full-time education at the time of the surveys. As noted above, it is permissible, and also customary in Britain, for secondary age pupils to hold part-time jobs (see Roberts, 1967). This has been valued for the experience of being an employee and, by young people, for the financial independence that it confers, always amid fears that educational attainments might suffer (Mizen et al., 1999). During the 1990s and 2000s, there was a slow decline in the prevalence of part-time employment of school age youth (see Conlon et al., 2015), and an unresolved debate about whether this was due to the young people's desire to concentrate on their studies or competition for the jobs from older age groups. Between 2019 and 2021, their employment rate fell from 22 percent to 14 percent. During the 1990s and 2000s, it became increasingly common for higher education students to take part-time jobs. This was amid the same debates that had previously focused on young people of secondary school age (see Howieson et al., 2012; Lucas, 1997). The rise of parttime job holding among university students followed the replacement of government maintenance grants with loans, and the failure of the loans to cover full living costs. Their chances of being in employment declined during the lockdowns of 2020 and 2021 from 35 percent to 31 percent, a more modest decline than among 16 and 17 year olds.

Table 3 shows that rates of employment and unemployment among 18 - 24 year olds who had completed full-time education remained constant throughout 2020 and early-2021. However, we must bear in mind that furloughed staff were counted as employed in Labour Force Surveys. The rise in recorded youth unemployment during and following the first lockdown, then the partial recovery in employment, were entirely among the students in both age groups, especially $16-17$ year olds.

\subsection{Unequal Risks}

Throughout the pandemic and Brexit, rates and risks of unemployment remained responsive to some "traditional" predictors-specifically educational qualifications and ethnicity. Table 4 shows that throughout 2020 rates of unemployment among the UK's 16 - 24 year olds rose among those with all levels of qualifications. No level of qualification was especially protective. However, throughout the year A-levels and higher qualifications were associated with reduced risks of 
unemployment even though during the year unemployment rose as steeply among the best as among the least qualified. However, the largest absolute rise in unemployment rates was among the least qualified. By the end of 2020, the latter's unemployment rate was 33 percent. "None" in Table 4 does not necessarily mean that the young people had literally no qualifications. Rather they lacked qualifications normally gained at age 16 which would have enabled them to progress to courses on which they could gain post-GCSE qualifications. Here we should recall that unemployment was most common among 16 - 24 year olds who were still in full-time education.

Table 3. UK youth employment by age groups and educational status during 2020.

\begin{tabular}{|c|c|c|c|c|}
\hline & $\begin{array}{l}16-17 \\
\text { in full-time } \\
\text { education }\end{array}$ & $\begin{array}{c}16-17 \\
\text { not in full-time } \\
\text { education }\end{array}$ & $\begin{array}{c}18-24 \\
\text { in full-time } \\
\text { education }\end{array}$ & $\begin{array}{c}18-24 \\
\text { not in full-time } \\
\text { education }\end{array}$ \\
\hline \multicolumn{5}{|c|}{ May-July 2019} \\
\hline Employed & 22 & 46 & 35 & 76 \\
\hline Unemployed $^{\star}$ & 19 & 21 & 11 & 10 \\
\hline Inactive & 73 & 42 & 61 & 15 \\
\hline \multicolumn{5}{|c|}{ May-July 2020} \\
\hline Employed & 21 & 29 & 33 & 75 \\
\hline Unemployed $^{\star}$ & 22 & 34 & 17 & 11 \\
\hline Inactive & 73 & 56 & 60 & 15 \\
\hline \multicolumn{5}{|c|}{ August-October 2020} \\
\hline Employed & 15 & 32 & 34 & 74 \\
\hline Unemployed $^{\star}$ & 30 & 32 & 18 & 13 \\
\hline Inactive & 78 & 53 & 59 & 15 \\
\hline \multicolumn{5}{|c|}{ October-December 2020} \\
\hline Employed & 15 & 43 & 32 & 76 \\
\hline Unemployed ${ }^{\star}$ & 27 & 19 & 16 & 12 \\
\hline Inactive & 80 & 47 & 62 & 14 \\
\hline \multicolumn{5}{|c|}{ January-March 2021} \\
\hline Employed & 12 & 40 & 31 & 77 \\
\hline Unemployed $^{\star}$ & 29 & 26 & 12 & 11 \\
\hline Inactive & 83 & 46 & 65 & 13 \\
\hline \multicolumn{5}{|c|}{ April-June 2021} \\
\hline Employed & 14 & 32 & 31 & 78 \\
\hline Unemployed $^{\star}$ & 34 & 30 & 16 & 9 \\
\hline Inactive & 79 & 54 & 63 & 14 \\
\hline $\begin{array}{c}\text { Percentages of } \\
\text { age groups }\end{array}$ & 93 & 7 & 38 & 62 \\
\hline
\end{tabular}

Source: Office for National Statistics, Labour Force Surveys. ${ }^{*}$ Percentage of employed (including self-employed) plus unemployed. Therefore the vertical totals exceed $100 \%$. 
Table 4. Unemployment rates*, 16 - 24 year olds by highest educational qualification, in percentages.

\begin{tabular}{ccccc}
\hline & Degree & A-level & GCSE & None \\
\hline October-December 2019 & 8 & 8 & 15 & 24 \\
October-December 2020 & 13 & 12 & 19 & 33 \\
\hline
\end{tabular}

Source: Office for National Statistics, Labour Force Surveys. ${ }^{\star}$ Percentage of employed (including self-employed) plus unemployed.

During 2020, unemployment among young women rose more steeply than among young males. However, this was due entirely to young women's higher participation rate in post-18 education and their enhanced vulnerability to the shortage of students' part-time jobs. Table 5 shows that during 2020 young women in full-time education were actually more likely than males to hold on to part-time jobs, from which both sexes were likely to be furloughed. There was little difference in chances of being in employment, or risks of unemployment, between young men and women who had completed full-time education.

Ethnicity made a greater difference than either sex or qualifications to labour market prospects during 2020. There were huge differences between ethnic groups in rates of unemployment at the beginning and at the end of the year. Moreover, the unemployment rate among "whites" rose more modestly during 2020 than the rates among all the non-white minorities in Table 6. In the closing months of 2020 Black youth had an unemployment rate of 42 percent. These ethnic disparities would have been partly due to all non-white minorities being more likely than whites to continue in education beyond age 18 and achieve university degrees, but the disparities are also due to an ethnic penalty in UK labour markets that has survived all equal opportunities laws and initiatives (Commission on Race and Ethnic Disparities, 2021).

\subsection{Starter Jobs}

In contrast to the protection offered to young people who were still in education, and to those already established in employment, the special assistance offered by the government to young people leaving education and seeking their first jobs looked puny. On $8^{\text {th }}$ July 2020 , the government announced a wave of new measures for the otherwise young unemployed. These measures were extended and enhanced in November 2020 (Chancellor of the Exchequer, 2020). The measure intended to be of particular assistance to young people seeking their first jobs was the Kick Start scheme which replicated the Future Jobs Fund that assisted 105,000 young people between 2009 and 2011 (Department for Work and Pensions, 2012). Under Kick Start the government budgeted for paying the legal minimum wage for up to six months to up to 250,000 under 25 year olds who would be recruited to new jobs and who were at risk of becoming or had already become unemployed. An accompanying Restart scheme offered similar support to older workers who had been unemployed for 12 months or more. 
Table 5. Youth employment by age groups and sex, November 2020-January 2021, in percentages.

\begin{tabular}{ccccc}
\hline & $\begin{array}{c}16-17 \\
\text { in full-time } \\
\text { education }\end{array}$ & $\begin{array}{c}16-17 \\
\text { not in full-time } \\
\text { education }\end{array}$ & $\begin{array}{c}18-24 \\
\text { in full-time } \\
\text { education }\end{array}$ & $\begin{array}{c}18-24 \\
\text { not in full-time } \\
\text { education }\end{array}$ \\
\hline Males & 12 & 37 & 21 & 73 \\
\hline Employed & 31 & 23 & 16 & 15 \\
Unemployed & 83 & 52 & 68 & 14 \\
Inactive & 16 & 35 & 36 & 76 \\
Females & 27 & 27 & 16 & 10 \\
\hline Employed & 78 & 52 & 57 & 16 \\
Unemployed & 16 & & & \\
Inactive & & & & \\
\hline
\end{tabular}

Source: Office for National Statistics, Labour Force Surveys. ${ }^{\star}$ Percentage of employed (including self-employed) plus unemployed.

Table 6. Unemployment rates ${ }^{\star}, 16$ - 24 year olds by ethnic groups, in percentages.

\begin{tabular}{lcccc}
\hline & White & Indian & Pakistani/Bangladeshi & Black \\
\hline October-December 2019 & 10 & 10 & 23 & 25 \\
October-December 2020 & 12 & 24 & 32 & 42 \\
\hline
\end{tabular}

Source: Office for National Statistics, Labour Force Surveys. ${ }^{\star}$ Percentage of employed (including self-employed) plus unemployed.

In addition to Kick Start, there was to be money for additional apprenticeships and traineeships, vocational education and counselling, job coaches, and anyone without at least an A-level pass was to be offered free college courses that delivered "skills valued by employers" (Department for Education, 2021). New "T" vocational qualifications were being introduced, with employers in charge of the curricula. Hence the "guarantee" that the qualifications and skills would be valued by employers. However, these claims had been made during the introduction of earlier waves of new vocational qualifications, including those awarded by the Business and Technology Education Councils (eventually merged into BTECs), and the National Vocational Qualifications that were launched in the mid-1980s.

Kick Start was the sole initiative that was operating by mid-2021. Despite the funding that the government had made available, by January 2021, only just over 2000, young people had been recruited onto Kick Start. Levels of unemployment among young people who had left full-time education were being contained without assistance from any of the new measures. By the end of 2020, there was already evidence that both education (higher enrolments as described above) and the labour market (see below) were adapting to pandemic, post-pandemic and post-Brexit conditions. 
Apprenticeship starts by 16 - 24 year olds (see Table 7) offer one indication of 2020 and onwards trends in Britain's youth labour markets. Starts fell from 196,000 in 2018-2019 to 170,000 in 2019-2020, and most of this decline was during the pandemic months. Despite the additional government money that had been made available, whereas 13,100 had started apprenticeships in July 2019, only 6,300 did so in July 2020. This accounted for the greater part of the decline in total starts by 16 - 24 year olds between 2018-2019 and 2019-2020. Against this trend, recruitment to higher apprenticeships (a small minority of the total) actually rose. The scale of the drop in apprenticeship starts, and the resilience of higher apprenticeships, continued throughout the remainder of 2020 (Department for Education, 2020b). This is an indication that well-qualified young people were

Table 7. Apprenticeship starts by age.

\section{August 2018-July 2019 (in thousands)}

\begin{tabular}{ccccc}
\hline & $<\mathbf{1 9}$ & $\mathbf{1 9 - 2 4}$ & Older & Total \\
\hline Intermediate & 49 & 36 & 46 & 131 \\
Advanced & 35 & 52 & 74 & 162 \\
Higher & 4 & 19 & 48 & $71^{\star}$ \\
Total & 89 & 107 & 168 & 364 \\
\hline
\end{tabular}

Includes 13.5 K degree apprenticeships (Lester \& Bravenboer, 2020).

August 2019-July 2020 (in thousands)

\begin{tabular}{ccccc}
\hline & $<19$ & $\mathbf{1 9}-\mathbf{2 4}$ & Older & Total \\
\hline Intermediate & 39 & 27 & 33 & 99 \\
Advanced & 32 & 44 & 62 & 139 \\
Higher & 4 & 23 & 55 & 81 \\
Total & 76 & 94 & 149 & 319 \\
\hline
\end{tabular}

\begin{tabular}{ccccc}
\hline & \multicolumn{5}{c}{ July 2019} & \\
\hline & $<19$ & $19-24$ & Older & Total \\
\hline Intermediate & 3200 & 3000 & 3700 & 990 \\
Advanced & 2600 & 3500 & 6000 & 12200 \\
Higher & 100 & 700 & 2800 & 3600 \\
Total & 5900 & 7200 & 12,500 & 25,600 \\
\hline & & July 2020 & & \\
\hline Intermediate & 1100 & $19-24$ & Older & Total \\
Advanced & 1000 & 1600 & 2500 & 5200 \\
Higher & 100 & 2600 & 4400 & 7900 \\
Total & 2200 & 900 & 3900 & 4800 \\
\hline
\end{tabular}

Source: Department for Education (2020a, 2020b). 
continuing to be recruited to apprenticeships during the pandemic. Employers will only kick-start school, college and university leavers' careers if the employers expect to have jobs in which the recruits can be retained. This appears to have applied to better-qualified leavers in 2020-2021, but not to those whose most likely pre-pandemic destination was a middling occupation via an intermediate apprenticeship.

High Fliers Research $(2020,2021)$ found that the recruitment plans of top graduate employers, those offering the prospect of elite careers, declined by only 11 percent between 2019 and 2020 and a further three percent decline was envisaged in 2021. Neither the decline in apprentice starts nor the decline in the recruitment by employers to the most sought graduate jobs was registering in Labour Force Surveys at the end of 2020. Rises in youth unemployment had been entirely among groups still in full-time education. This suggests that, unlike the experiences of high fliers, those whose entry into occupations considered commensurate with their qualifications was blocked were either prolonging their education or stepping down the occupational structure which would lead to an increased concentration of unemployment among the least qualified young people. Low paid jobs requiring minimal training were among the more resilient during and following Britain's lockdowns. Businesses and jobs in hospitality bounced back as soon as lockdowns ended. Additional jobs were created during lockdowns in supermarkets (which remained open), and especially in distribution centres for online retail sales, and delivering goods on foot, by bicycle and motorised transport.

\section{Discussion}

During the first UK lockdown in 2020, when 20 percent was suddenly ripped from the country's GDP, it seemed inevitable that unemployment would climb steeply, most of all, on the basis of past experience, among young people. Twelve months forward in March 2021, when the number of payrolled employees was 814,000 down on March 2020 (Office for National Statistics, 2021b), it seemed surprising that jobs losses among young people had been confined to students seeking part-time employment, and among students to relatively vulnerable groups, namely those with no qualifications and non-white minorities, especially Black youth. However, during 2020 rises in youth unemployment in most European countries were modest, and rates of unemployment had ceased rising or even begun to decline in 2021. Any damage to the UK labour force from Brexit lay in the future. The UK's exit from the single market at the end of 2020 led immediately to a decline of over 20 percent in trade with the European Union, with UK exporters and importers complaining of delays at borders, and increased customs and administration costs (De Lyon \& Dhingra, 2021; Office for National Statistics, 2021c).

Youth unemployment had been contained by similar mixtures of measures in all European countries: delays to exiting education, job retention schemes (furloughing in the UK), life support for businesses and increased government spend- 
ing. Governments needed to spend to cope with the pandemic: on protective clothing and equipment for health service staff, on testing for infections and contract tracing, then in some countries on developing and everywhere on administering vaccines.

In the short-term, Brexit created job vacancies in immigration and customs services. The Brexit vote in 2016 led immediately to a sustained rise in EU nationals quitting the UK, and during the 12 months surrounding the UK's exit from the single market (2020-2021) 1.3 million non-nationals left the country. However, throughout the Brexit process there were compensating inflows of nonnationals, and net migration remained positive so labour supply was not depressed though some businesses did experience labour shortages where, for example, it was impossible in the short-term to replace the skills, qualifications and experience of lorry-drivers who were returning to EU countries. Also, at the end of 2020, there was a 20 percent gap between government revenue and spending, and national debt was predicted to equal to 97.5 percent of GDP by 2025-2026, a level unprecedented since the end of the Second World War (Chancellor of the Exchequer, 2020). Youth of the pandemic years will repay this debt throughout their working lives, as did the post-1945 baby boomers.

Maybe we should look at other life domains, and at a different age group rather than young people exiting education and seeking employment in 2020 and 2021, for long-term damage inflicted by the pandemic and lockdowns. These are known to have led to declines in children's and young people's mental well-being (Banks \& Xu, 2020; Mental Health Foundation, 2020; Sehmi \& Slaughter, 2021). In 2020 and 2021, more pupils than formerly were leaving primary school without basic skills of literacy and numeracy. There were fears that they might never recover (Crenna-Jennings et al., 2021). Other age groups were being affected by lockdowns in ways that would have consequences for their later transitions into the labour market. In autumn 2020, following the first national lockdown, the number of pupils in England's schools who were absent more often than present rose by 30,000 . Another increase was expected in autumn 2021 following the second and third national lockdowns. There was concern that these children were becoming available for recruitment by criminal gangs, specifically those distributing drugs. There were increases between 2020 and 2021 in notified cases of drug misuse by a child (23 percent) and trafficking (21 percent) (Savage, 2021).

During the 1980s and 1990s the NEET rate among young people in the UK fell steadily, attributable to a decline in the proportion leaving education without any (useful) qualifications and fewer young women having children. There was no further decline in NEET rates from 2000 onwards. A decline in mental health among young people was then applying upward pressure on these rates (Holmes et al., 2021) to which the effects of lockdowns will be added in the 2020s. Britain is likely to experience simultaneous rises in the proportions of young people gaining qualifications that enable them to progress through higher education, and also in the numbers with no useful qualifications who effectively disengage long before age 18 up to when they are legally required to be in full-time learning. 
There are further ways in which the pandemic and lockdowns may have scarred young people's futures. Failure to acquire cultural and sporting tastes and skills, normally (but not during lockdowns) nurtured in families and practised using community facilities in the primary school age group, then consolidated while at secondary school (Glevarec et al., 2020; Haycock \& Smith, 2014; Smith et al., 2015; Wheeler \& Green, 2014), could impoverish future lives.

That said, the age group making education-to-work transitions in 2020 and 2021 deserves further attention. We may be misled if we focus exclusively on unemployment and NEET rates. These are important because they are known to be indicators of long-term scarring (Tumino, 2015). However, rises and declines in unemployment may lag years behind changes in GDP. In the recession of the 1980s UK GDP ceased to fall in 1982 but unemployment continued to rise until 1986. Also, a single digit, a snapshot of the percentage of the workforce unemployed at one point in time, merges one-off spells of unemployment, recurrent episodes of joblessness, and long-term uninterrupted unemployment (Roberts, 2016). Employment includes equally diverse situations. As measured in Labour Force Surveys it may mean no more than having worked for one hour during the previous week. Jobs vary in hours of work, rates of pay and longer-term career prospects.

A long-term pre-pandemic trend was towards a decline in the labour market value of all levels of educational qualifications (Roberts, 2020a). In 2020 university was still the principal route into elite careers, but there were far too many graduates for most to be accommodated. The lower middle class had become the most common graduate destination. Throughout the post-1980s expansion of higher education and the introduction of student fees, charged to students but covered by government loans during their studies, there had been persistent interest in whether university education was still "worth it", or whether the enlarged inflows of graduates were over-qualified for the employment that they are able to obtain. There are alternative ways of measuring whether university is "worth it" (Belfield et al., 2018; Office for Students, 2021; Purcell \& Elias, 2004; Purcell et al., 2012). All the measurements are fit for the investigators' purposes but yield rather different answers. However, a simple mathematical truth is that the roughly 15 percent of young people who completed university in the 1970s could conceivably be accommodated in the top 15 percent of jobs whereas this is impossible for 40 percent of a cohort. Many will necessarily move into middling occupations. If they displace downwards those with lesser qualification, the "graduate premium" can be preserved. This is a measurement favoured by university managements. Ominously, even before the pandemic it was estimated that a third of graduates would make no repayments on their student loans, which means that their earnings would never exceed the median, the point at which repayments then began (Hillman, 2021).

After a record proportion of 18/19 year olds had applied for and were admitted to the UK's universities in 2020/2021, and after the country exited lockdowns in 2021, pre-pandemic recruitment to elite careers had been almost maintained. 
Many of these careers are in health, education and other public services. Others are in investment banking and corporate management where levels of employment and remuneration have been maintained. Judged by the number of government-supported apprenticeship starts, it has been the middle levels of the occupational structure where opportunities for new starters have contracted sharply. If all cannot be accommodated in elite or lower middle class careers, where will the excess graduates go? Those who decide to wait while taking or extending their occupancy in what would otherwise have been student jobs could become a UK version of the thousand Euro generations in Italy, identified in the 2000s by Incorvaia and Rimassa (2008). These graduates were continuing to live and work like students after entering their thirties. However, in Northern Europe there are long-term career penalties for exiting university into a low-level job (Vobemer \& Schuck, 2016). Even so, UK graduates may find that they have no better options along with employees in higher-level occupations of all ages who lockdowns displaced from their former jobs. UK state welfare offers a lower salary replacement rate than other North European countries (Gustafason et al., 2021). The unemployed will be pressured into any jobs, however low the pay and however few the hours, with a tax credit salary top-up to the minimum income that the state deems tolerable. The alternative will be total withdrawal of benefit. This will be how, by the 2020s, the UK youth transition regime (Roberts, 2020a) in which both higher education and precarious employment seemed capable of further expansion, appeared equipped to adapt to post-pandemic and post-Brexit changes without youth unemployment and NEET rates spiralling upwards.

Bell et al. (2021) argue that the 2020s will be a decisive decade for the UK. The economy might leap from a low productivity, low pay equilibrium by investing in high productivity industries and occupations. However, high productivity is usually achieved with a low volume of employment. The volume of well-qualified labour available at low cost, coupled with path dependence, may prove decisive in keeping the UK in its pre-pandemic equilibrium, but in 2021, it was too soon to tell. Education-to-work transitions in post-pandemic and post-Brexit Britain will need monitoring throughout the 2020s before we can tell finally if and how the pandemic, lockdowns and Brexit have made a difference.

\section{Conclusion}

The UK's transition regime (see Roberts, 2020a), reinforced temporarily with the protection offered to "insiders" - "no detriment" policies for students taking crucial examinations, and furloughing for existing employees-prevented youth unemployment and NEET rates spiking during the pandemic lockdowns in 2020 2021. Rises in unemployment were confined to students seeking part-time jobs, and among them to particularly vulnerable groups, namely the least qualified and nonwhite ethnic minorities. However, maintaining the relatively smooth education-towork transitions of the remainder involved more higher education graduates "stepping down" into jobs for which they were over-qualified, placing their entire fu- 
ture careers and earnings at risk, and an enlarged tail-end of low achievers who were at risk of becoming trapped in low-paid precarious jobs.

That said, at present, all conclusions must be interim. It is still too early to draw any firm conclusions since none of the existing metrics capture exactly how, and how many young people's lives in education and in seeking employment have been affected by the pandemic, lockdowns and Brexit, and which if any effects will remain visible in later stages of their lives. Specifically and urgently, we need an up-to-date categorical class scheme (Roberts, 2020b). The occupational class has always been and remains our best indicator of life chances (Williams, 2017). In terms of unemployment rates, the impact of the pandemic and lockdowns has been less severe than the 2007-2009 financial crisis, and far less severe and sustained than the UK recession of the 1980s. However, the pandemic and lockdowns outscore the earlier disruptions in terms of how many pupils' and students' education, and employees' lives at (or not at) work, have been affected. These effects are not all captured in metrics of examination results, progression rates in education, or rates of employment and unemployment, though these statistics have the advantage of rapid availability.

The pandemic and lockdowns reinforce the case for disaggregating both employment and unemployment. The UK entered and exited the lockdowns with high employment rates against its own historical and current international standards but, in a European context, with a high proportion of employment in low productivity, low paid or otherwise precarious jobs in terms of maintaining a normal adult life. These are the jobs that bounced back rapidly as soon as hotels, restaurants, entertainment and tourism were released from lockdowns and social distancing. Brexit, pandemic and lockdown jolts could propel the UK out of, or the country could resettle quickly, along with many other parts of the old West, into a post-industrial niche as a relatively stagnant backwater in the $21^{\text {st }}$-century global economy. In this case, the inter-generational decline in life chances that began in the late $20^{\text {th }}$ century (see Roberts, 2012) will continue.

\section{About the Author}

Ken Roberts is Emeritus Professor of Sociology at the University of Liverpool. His books include Surviving Post-Communism: Young People in the Former Soviet Union (2000), Youth in Transition: Eastern Europe and in the West (2009), Class in Contemporary Britain (2011), Sociology: An Introduction (2012), The Business of Leisure (2016), Social Theory, Sport, Leisure (2016), and Youth in Saudi Arabia (2018).

\section{Conflicts of Interest}

The author declares no conflicts of interest regarding the publication of this paper.

\section{References}

Adams-Prassl, A., Boneva, T., Golin, M., \& Rauh, C. (2020). Furloughing. Cam- 
bridge-INET Working Paper 2036. https://doi.org/10.1111/1475-5890.12242

Ball, C. (2021). UK Graduate Labour Market Update: 8 June. Prospects.

Banks, J., \& Xu, X. (2020). The Mental Health Effects of the First Two Months of Lockdown and Social Distancing during the Covid-19 Pandemic in the UK. Working Paper W20/16, Institute for Fiscal Studies. https://doi.org/10.1111/1475-5890.12239

Belfield, C., Britton, J., Buscha, F., Dearden, L., Dickson, M., van der Erve, L., Sibieta, L., Vignoles, A., Walker, I., \& Zhu, Y. (2018). The Impact of Undergraduate Degree on Early-Career Earnings. Institute for Fiscal Studies.

Bell, T., Dhingra, S., Machin, S., McCurdy, C., Overman, H., Thwaites, G., Tomlinson, D., \& Valero, A. (2021). The UK's Decisive Decade. Resolution Foundation.

Brewer, M., \& Handscomb, K. (2020). All Together Now? Resolution Foundation.

Brewer, M., Cominetti, N., Henehan, K., McCurdy, C., Sehmi, R., \& Slaughter, H. (2020). Jobs, Jobs, Jobs. Resolution Foundation.

Chancellor of the Exchequer (2020). Spending Review 2020.

Cominetti, N. (2021). A U-Shaped Crisis: The Impact of the Covid-19 Crisis on Older Workers. Resolution Foundation.

Commission on Race and Ethnic Disparities (2021). Commission on Race and Ethnic Disparities: The Report. Cabinet Office, Government UK.

Conlon, G., Patrignani, P., \& Mantovani, I. (2015). The Death of the Saturday Job: The Decline in Earning and Learning amongst Young People in the UK. UK Commission for Employment and Skills.

Crenna-Jennings, W., Perera, N., \& Sibieta, L. (2021). Education Recovery and Resilience in England. Education Policy Institute.

De Lyon, J., \& Dhingra, S. (2021). The Impacts of Covid-19 and Brexit on the UK Economy: Early Evidence in 2021. Ciovid-19 Analysis Series, No. 021, Centre for Economic Performance, London School of Economics.

Department for Education (2020a). Apprenticeships and Traineeships, England: October 2020. Department for Education.

Department for Education (2020b). Apprenticeships and Traineeships, Academic Year 2019/20. Department for Education.

Department for Education (2021). Skills for Jobs: Lifelong Learning for Opportunity and Growth. Department for Education.

Department for Work and Pensions (2012). Impacts and Costs and Benefits of the Future Jobs Fund. Department for Work and Pensions.

Glevarec, H., Nowak, R., \& Mahut, D. (2020). Tastes of Our Time: Analysing Age Effects in the Contemporary Distribution of Music Tastes. Cultural Trends, 29, 182-198. https://doi.org/10.1080/09548963.2020.1773247

Gustafason, M., Henehan, K., Rahman, F., \& Tomlinson, D. (2021). After Shocks: Financial Resilience before and during the Covid-19 Crisis. Resolution Foundation.

Haycock, D., \& Smith, A. (2014). A Family Affair? Exploring the Influence of Childhood Sport Socialisation on Young Adults' Leisure Sports Careers in North-West England. Leisure Studies, 33, 285-304. https://doi.org/10.1080/02614367.2012.715181

Henehan, K. (2020). Class of 2020: Education Leavers in the Current Crisis. Resolution Foundation.

High Fliers Research (2020). The Graduate Market in 2020. High Fliers Research.

High Fliers Research (2021). End of Year Review: The Graduate Market in 2020. High Fliers Research. 
Hillman, N. (2021). No Easy Answers: English Student Finance in the Spending Review. HEPI Policy Note 31, Higher Education Policy Institute.

Holmes, C., Murphy, E., \& Mayhew, K. (2021). What Accounts for Changes in the Chances of Being NEET in the UK? Journal of Education and Work.

https://doi.org/10.1080/13639080.2021.1943330

Howieson, K., McKenzie, J., Hobbs, S., \& Semple, S. (2012). New Perspectives on Students' Part-Time Work. Sociology, 40, 322-338.

https://doi.org/10.1177/0038038511419183

Incorvaia, A., \& Rimassa, A. (2008) Generation 1000 Euro. Goldman Verlag.

Lester, S. \& Bravenboer, D. (2020). Sustainable Degree Apprenticeships. Centre for Degree Apprenticeships.

Lucas, R. (1997). Youth, Gender and Part-Time Work-Students in the Labour Process. Work, Employment and Society, 112, 595-614. https://doi.org/10.1177/0950017097114001

Major, L. E., \& Machin, S. (2020). Covid-19 and Social Mobility. CEP Covid-19 Analysis, Paper 004, Centre for Economic Performance, London School of Economics.

Major, L. E., Eyles, A., \& Machin, S. (2020). Generation COVID: Emerging Work and Education Inequalities. Covid-19 Paper 011, Centre for Economic Performance, London School of Economics.

Mental Health Foundation (2020). The COVID-19 Pandemic, Financial Inequality and Mental Health. Mental Health Foundation.

Mizen, P., Bolton, A., \& Pole, C. (1999). School Age Workers: The Paid Employment of Children in Britain. Work, Employment and Society, 13, 423-438.

https://doi.org/10.1177/09500179922118015

Office for National Statistics (2021a). Employee Earnings in the UK: 2020. Office for National Statistics.

Office for National Statistics (2021b). Labour Market Overview, UK: April 2021. Office for National Statistics.

Office for National Statistics (2021c). UK Trade: June 2021. Office for National Statistics.

Office for Students (2021). Projected Completion and Employment from Entrant Data (Proceed). Office for Students.

Purcell, K., \& Elias, P. (2004). Seven Years On: Graduate Careers in a Changing Labour Market. Higher Education Careers Service Unit.

Purcell, K., Elias, P., Atfield, G., Behle, H., Ellison, R., Luchinskaya, D., Snape, J., Conaghan, L., \& Tzanakow, C. (2012). Futuretrack Stage 4: Transitions into Employment, Further Study and Other Outcomes. Warwick Institute for Employment Research.

Roberts, K. (1967). The Incidence and Effects of Spare Time Employment amongst SchoolChildren. Vocational Aspect, 43, 129-136. https://doi.org/10.1080/03057876780000141

Roberts, K. (2012). The End of the Long Baby Boomer Generation. Journal of Youth Studies, 15, 479-497. https://doi.org/10.1080/13676261.2012.663900

Roberts, K. (2016). Unemployment. In S. Edgell, H. Gottfried, \& E. Granter (Eds.), The Sage Handbook of the Sociology of Work and Employment (pp. 469-484). Sage. https://doi.org/10.4135/9781473915206.n25

Roberts, K. (2020a). Regime Change: Education to Work Transitions in England, 1980s-2020. Journal of Applied Youth Studies, 3, 21-42.

https://doi.org/10.1007/s43151-020-00004-6

Roberts, K. (2020b). Dealignment: Class in Britain and Class in British Sociology since 1945. Societies, 10, 79. https://doi.org/10.3390/soc10040079 
Rooney, S. (2019). Normal People. Faber.

Savage, M. (2021). Thousands of Pupils Will Fall off the Grid When School Reopen. The Observer, August 8.

Schoon, I., \& Henseke, G. (2021). Career Ready? UK Youth during the Covid-19 Crisis. Covid-19 Youth Economic Activity and Health (YEAH) Monitor Briefing 2, LLAKES, University College London.

Sehmi, R., \& Slaughter, H. (2021). Double Trouble: Exploring the Labour Market and Mental Health Impact of Covid-19 on Young People. Resolution Foundation.

Smith, L., Gardner, B., Aggio, D., and Hamer, M. (2015). Association between Participation in Outdoor Play and Sport at Age 10 Years Old with Physical Activity in Adulthood. Preventive Medicine, 74, 31-35. https://doi.org/10.1016/j.ypmed.2015.02.004

The British Academy (2021). Shaping the Covid Decade: Addressing the Long-Term Impacts of Covid-19. The British Academy.

Trade Union Congress (2020). Young Workers Are Most at Risk from Job Losses Due to the Coronavirus Crisis. Trade Union Congress.

Tumino, A. (2015). The Scarring Effect of Unemployment from the Early' 90s to the Great Recession. Institute of Social and Economic Research, Working Paper 2015-05, University of Essex.

Villadsen, A., Conti, G., \& Fitzsimons, E. (2020). Parental Involvement in Home Schooling and Developmental Play during Lockdown. Briefing, Centre for Longitudinal Studies, University College London.

Vobemer, J., \& Schuck, B. (2016). Better Overeducated than Unemployed? The Shortand Long-Term Effects of an Overeducated Labour Market Entry. European Sociological Review, 32, 251-265. https://doi.org/10.1093/esr/jcv093

Wheeler, S., \& Green, K. (2014). Parenting in Relation to Children's Sport Participation: Generation Changes and Potential Implications. Leisure Studies, 33, 267-284. https://doi.org/10.1080/02614367.2012.707227

Wielgoszewska, B., Green, F., \& Goodman, A. (2020). Finances and Employment during Lockdown. Briefing, Centre for Longitudinal Studies, University College London.

Williams, M. (2017). Occupational Stratification in Contemporary Britain: Occupational Class and the Wage Structure in the Wake of the Great Recession. Sociology, 51, 1299-1317. https://doi.org/10.1177/0038038517712936 